Article 138

Received: March 9, 2017

Accepted: April 28, 2017
Journal of Electrical Engineering and Information Technologies, Vol. 2, No. 1, pp. 59-69 (2017)

In print: ISSN 2545-4250

On line: ISSN 4245-4269

UDC: 654:658.86]:005.34

Original scientific paper

\title{
BUSINESS MODELS FOR MANAGEMENT OF SALES CHANNELS IN TELECOMMUNICATION COMPANIES
}

\author{
Petar Damjanovski, Aleksandar Risteski \\ Faculty of Electrical Engineering and Information Technologies, \\ "Ss. Cyril and Methodius" University in Skopje, \\ Rugjer Bošković bb, P.O. box 574, 1001 Skopje, Republic of Macedonia \\ petar.damjanovski@gmail.com
}

\begin{abstract}
A b s t r a c t: The paper presents business models for sales channels management in telecommunications companies; presenting international experience and best practices that are present among worldwide biggest players in telecom business. Based on their experience and detailed research explained in this paper, the authors proposed Values Based (VB) business models, as future proved model for steering telecom companies in near future. Moreover, based on VB business model we are presenting a detailed explanation of a sales channels motivation system in a telecommunications company; IT infrastructure alignment and Network infrastructure implementation required for IT Tool that will support the motivation system.
\end{abstract}

Key words: value based steering; business model in telecommunications; motivation system for sales channels in telecommunications; market invest

\section{ДЕЛОВНИ МОДЕЛИ ЗА УПРАВУВАЊЕ СО ПРОДАЖНИ КАНАЛИ ВО ТЕЛЕКОМУНИКАЦИСКИ КОМПАНИИ}

\begin{abstract}
А п с т р а к т: Трудот ги презентира деловните модели за управување со продажни канали во телекомуникациски компании; како и интернационалните искуства и најдобрите практики кои се користени од страна на најголемите светски распространети телекомуникациски компании. Врз основа на нивните искуства и деталните истражувања објавени во овој труд, авторите препорачуваат вредносно базиран бизнисмодел како модел на иднината за управување со телекомуникациските компании. Дополнително, врз основа на претставениот модел детално се обработени системот за мотивација на продажни канали во телекомуникациски компании; интеграција на IT инфраструктура и имплементацијата на Мрежната инфраструктура потребни како IT алатки кои го поддржуваат системот за мотивација.
\end{abstract}

Клучни зборови: управување базирано на вредност; бизнис модели во телекомуникации; мотивациски системи за продажни канали во телекомуникации; инвестирање во пазар

\section{INTRODUCTION}

With the development of the telecommunications and the appearance of new different services and different types of technologies through which they are available, the increased number of competitive operators, there is a need of introducing new models that will develop the business. These models aim to bring together all the basic corporate indicators coming from different fields of the company, such as marketing, sales, finance, strategy, and technology. Each telecom operator owns several types of telecommunications network. It is composed of different network segments and topologies, made by different producers. The networks are organized in different levels. There is IP/MPLS and WDM based transport infrastructure; a network for covering fixed services; a separate network for mobile service customers based on GPRS, GPRS, EDGE, 3G, 4G; broad band network composed of different network types, such as ADSL, VDSL, DOCSIS, FTTX; networks based 
on IPTV distribution. For each of these network types, there is a different strategy and development planning. Networks have different costs, time of development and number of customers who can use it. From the financial perspective, each of the networks has a different price, which should be divided into initial investment, maintenance cost, and cost for transfer to a more modern type of network.

Another perspective of the telecommunications business is the one of the customers. Each customer has different needs and demands that the telecommunication service should provide. Each service has their own production cost, resources cost, sales price, and maintenance cost.

The above listed aspects should be framed into a business model which will balance among the demands, the resources and the abilities.

The key challenge to achieve this is creating a uniformed plan and a procedure for planning of the overall telecommunications network, encompassing a number of limitations to the previously defined aspects. The dimensions of time, space, and the level of details are additional limitations.

The business model and the planning should make a balance between the abilities and the demands.

An important factor in planning and creating the models is the level of development of the telecommunications market, e.g. whether the operator is a new or a dominant market player. The level of development of the country in which the business is developed, and the financial potential of the customers, the expected revenue per customer and the workforce costs also play an important role.

Historically, the planning foundations were set in the sphere of technology. At the very beginning of the development of the telecom industry, the main focus was put on developing an operational plan to optimize and speed up the establishment of the telecommunications network, e.g. finding a way to maximise the results with the available financial, human and technological resources, or to bring the voice service to each citizen. Technology development and the introduction of different types of telecommunications networks lead to the appearance of the problem of cross-level planning, which is important to optimize the resources of all types of networks. The aim is to optimize the costs and provide the most advanced technology, which will be sustainable for a long period of time. This is in particular important, considering the fast development of the industry.
The traditional methods of planning and business modelling of the telecommunications business in the newly developed market conditions become unproductive, i.e. they do not reflect the real business, and cannot ensure their development in a sustainable way. They are based on technology key performance indicators, which do not take into consideration the economic parameters. The traditional models are mainly based on volume of service lines, without taking into consideration the qualitative value parameters.

The remaining part of this paper is organized as follows: Section 2 gives an overview of the most relevant research works in this field. Section 3 presents the value based business model with a short overview, main principles of the methodology, detailed definitions of the basic Key Performance Indicators (KPIs) and benefits of the telcocompany. Section 4 gives an overview and methods for implementation of a system for motivation of the sales force in a telecommunications company. In Section 5 we provide IT and network implementation of the system. Finally, the last Section 6 concludes this paper.

\section{RELATED WORKS}

The methodology for development of a motivation system for sales channels in telecommunication is an interdisciplinary theory. For this reason, there are closely-related papers with a similar content for this subject in the areas of economy management and telecommunication. The main focus in this paper is an analysis of models for management of a telecommunications company based on value, and their practical usage with particular implementation.

This issue is elaborated in detail by H. M. Schoening [1], who devotes two full chapters in his publication. He creates a detailed observation and analyses the operational management in telecommunications. There is a detailed elaboration of planning methods in telecommunications, from strategic planning to detailed micro-project planning.

It the operational management [3] is not translated into a sales operational plan with welldefined sales targets allocated per sales representative [3], it will not be realized with positive results. Sales channel management was comprehensively addressed by the father of the modern management Philip Kotler [3]. He put special focus on the eva- 
luation of the sales force and on models for management of the sales force. According to Kotler, the profit is main KPI for success. This should be embedded in the strategy of almost every main, global, telecommunications operator, as a basis of value based management.

Eminent consulting companies from all over the world that work in area of telecommunications and management, recommend the value based steering model as the best managerial model into telecommunications industry. Some of them, such as KPMG Consulting and Mckinsey [6], use it as their own working model. Detecon International $\mathrm{GmbH}$ in one publication issued 2011 [7] determines this model of management of telecommunications company as a base for survival in the era of fast growing Over The Top (OTT) operators.

This paper will present specific implementation of models and an IT system, based on the value-based business models for sales workforce management in the telecommunications industry.

\section{VALUE BASED BUSINESS MODEL}

The value based business model is grounded on value-add maximization. value add is the total profit of all sales transactions within a life time of a customer.

$$
V A=P \cdot T \cdot Q
$$

where: $P$ is istransaction profit, $T$ is service customer life time, and $Q$ is the number of such services. Unlike the classic planning model that is mainly focused on the number of transactions, this model also considers the quality of the transactions.

The overall domain of the value based business model is an aggregate of the separate subdomains, which cover the overall work of a telecommunications company from different aspects. For example, the value of the customers segmented by the type of contract is the first dimension. The overall value added of the company is a sum of the value adds of the new customers, the customers with contracts with limited duration, and the outof-contract customers. Another dimension is based on the type of services provided by the company. The overall $V A$ is an aggregate of the $V A$ of the mobile service, the $V A$ of the fixed services, the $V A$ of the convergent services, and the $V A$ of the information communications technology (ICT) services.
In the traditional models for monitoring and planning of telecommunications businesses, KPIs include number of transactions, monthly revenue per customer, number of lost customers, and cost per customer line. When these indicators are used, it is difficult to make a comparison of the KPIs among different categories, such as: comparison of performance of sales of different technology, quality of results of different sales channels, quality of the regional sales, etc.

The value based model encompasses KPIs divided into two categories: basic and calculated. Basic KPIs are those linked to direct measurement of parameters, such as:

- number of transactions (customers),

- number of customers lost in the first months after the sales of the service,

- number of out-of-contract customers,

- revenue per customer,

- lifetime of the customer, as a customer of the telecommunications company,

- direct costs for using the service, costs for acquisition or keeping a customer,

- operational sales costs.

In addition to the basic KPIs, there are also calculated ones, with a pre-defined description and calculation method. These include:

- value add,

- value add per user,

- value add per lifetime,

- average net revenue per user,

- return on investment,

- period of return on investment.

These KPIs are monitored for a period of one year, and they are compared to the expected parameters of the company. They are also used to support the management in decision-making on new investments, providing information about the expected profit.

The indicators that compose the model can be grouped into four basic groups, as follows (Figure 1):

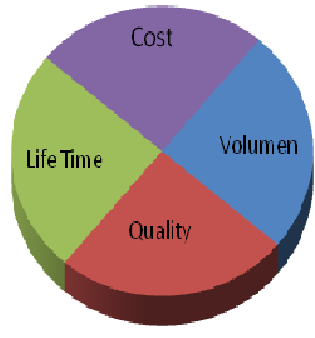

Fig. 1. Indicator groups 
According to the criterion for obtaining the results, the indicators are divided into calculated and predictive, based on the Cohort methodology. The former category includes the exact indicators, based on the specific data received from the database of the telecom operator; the latter are calculated based on a predefined methodology, based on value prediction of a specific indicator, based on historic data with similar characteristics, statistically calculated.

The first group of indicators, the quality indicators, measure and represent the quality of the customers that interact with the telecom operator. Indicators show the average revenue per user and the monthly subscription per user. They are grouped in several categories, by type of contract (acquisition or renewal), customer segmentation, and type of sales channel (retail, indirect sales, direct sales, etc.).

The key indicator, on which the methodology is based, is the average revenue per user (ARPU). It is represented at the level of a customer line, and it denotes a sum of the monthly subscription, revenue by traffic above the monthly subscription, interconnection revenue, and revenue based on additional services that are directly linked to the customer and the customer's line. It is expressed in a certain currency.

The way of its calculation depends on the type of a customer's contact that needs to be analyzed. When permanent users are analyzed, the calculations methods are based on real data, whereas for new users, due to the lack of historic data, the Cohort statistical method is used for value prediction.

The most frequently used Cohort method is calculation of average ARPU for customers for which historic data for three months is available, i.e. they became customers of the operator four months ago; they have the same tariff, and belong to the same customer segment. The average is taken as expected revenue for the new customer. The aim of this approximation is to determine the calculated indicators and to assess business development in the forthcoming period.

In addition to the basic usage of the ARPU indicator for acquiring a new customer, when customer's contacts for renewal of contracts are made, different types of sub-types of ARPU are used, as follows:

- ARPU per contract renewal;

- ARPU before contract renewal;

- ARPU of an out-of-contract customer;

- ARPU of a lost customer.
Each of the listed indicators has a specific role. The difference between the first two represents the net profit from customer contract renewal. ARPU of an out-of-contract customer is used for making a decision whether a certain group should proactively be covered with a customer contract. ARPU of a lost customer evaluates the quality of the lost customers.

The second category of the basic indicators is the indicators of volume or a number of customer interactions. They are divided into indicators for acquisition, and indicators for retain of customers.

The volume indicators on acquisition of new customers include new prepaid and post-paid service customers, as well as the indicator on early forced churn, directly linked to the number of new post-paid customers. The indicators on retaining customers include: number of renewed customer contracts of post-paid services, number of unsuccessfully renewed contracts or lost customers, number out-of-contract customers, average number of customers that are dismounted of the network, and number of customers with down sales migration from post-paid to prepaid and generate loss for the company.

The third group of indicators presents the average lifetime of the customer at the telecom operator. In the sub-category for concluding contracts with new customers, there is an indicator on the average lifetime of the acquired customers. The dimensions of renewal of customer contract include the lifetime of permanent customers, average lifetime of operators' out-of-contract customers, duration of contract after renewal, and average lifetime after migration form prepaid to post-paid.

The last, fourth group of indicators encompasses the cost-related indicators. They are grouped in two groups, direct costs related to service usage, and costs for acquisition and renewal of contract. Both categories are expressed in currency. Direct sales include interconnection costs, roaming costs and costs for additional services. The second group of costs is related to acquisition and renewal of customer contracts, and it includes costs for subsidising phones, service line cost, sales commission and incentive. For more thorough monitoring, one more level of detail is introduced, defined by an additional group of costs, i.e. costs specific for each sales channel. This subgroup is composed of the following types of costs: BTL advertising within one sales channel, rental, leasing, personnel costs for the employees, and IT costs. These costs are divided by sales channel, in 
order to have the profitability of each of them determined.

The calculated indicators are based on the basic four groups of indicators. These indicators are the ground of the model; the strategic goals of the company are defined and the business is managed based on their calculation. They are grouped into two groups:

- Primary: Value add $(V A / C M 2)$ and value add to long-term $\left(V A^{\prime} / C M 2^{\prime}\right)$.

- Secondary: Return on investment (RoMI) and period of return on investment.

$V A(C M 2)=\sum_{i=1}^{\substack{\text { total } \\ \text { volumen }}}\left(A R P U_{i}-\right.$ DirectCost 1$) \cdot$ LifeTime $-M I_{i}$

In which, ARPU is the average total monthly revenue per analyzed user, Direct Cost is the direct cost defined above in this paper, life Time is the number of months of the customer, and MI is investment in the customer, as SAC/SRC and sales realization costs.

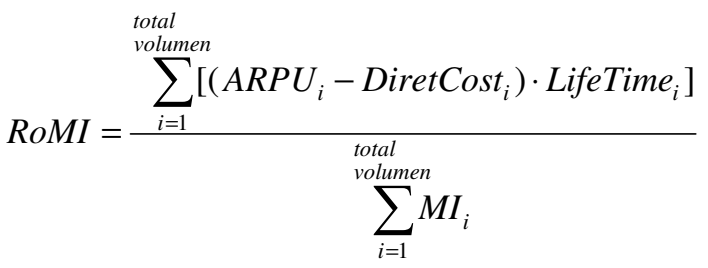

(3)

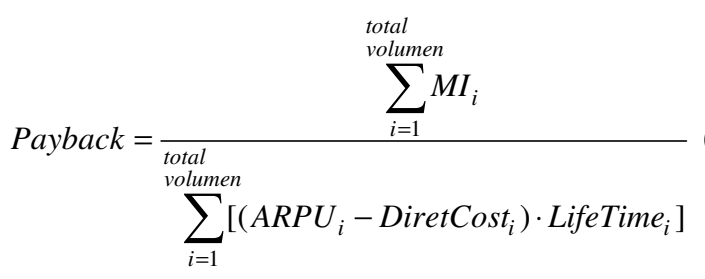

In which, RoMI is a calculated indicator that denotes how many times the investment will be returned $(M I)$, during the customer LifeTime.

Payback or return on investment - the number of months in which the investment will be returned $(M I)$.

The key advantages of the value based model are the higher flexibility and the greater level of detail in comparison to the traditional models based on planning of service lines and revenue. The flexibility is expressed through the ability to monitor all processes, all positive and negative transaction in a telecommunications company, by using the same indicators.
The general parameter $V A$ converts all types of customer transactions into a comparable unit, regardless to technology dimension, customer segmentation, type of service, sales channel, region, etc. In addition, this model easily illustrates other revenue and transactions that are not technically based, such as additional services, additional sales, etc. A great level of detail is enabled in all dimensions, and the advantages and the disadvantages are accurately located.

Each telecom operator that would like to ensure their future, expects convergent business and diversification of the business towards sales of insurance, energy etc., has to adjust and implement this or a similar model based on maximization of value add (VA).

\section{SYSTEM FOR MOTIVATION OF THE SALES CHANNELS}

Throughout the different periods of development of the telecommunications, different systems for motivation of sales force have been developed. The aim of these models is to establish a direct link between the motivation of the sales workforce and the defined company goals.

The models for motivation are directly related to the business management models with telecommunications companies. There has to be similar or equal set-up of the key indicators of business modelling and those of the sales force. Therefore, it can be concluded that motivation models have been developed simultaneously with the business management models of the telecommunications companies.

The development of the sales motivation systems has been significantly influenced by the development of the products (services) offered by the company. If the company has a wide portfolio, the motivation models should be adjusted to comprehensively cover the whole product portfolio, and ensure high quality sales for achieving company's business plans.

When the telecommunications company started to develop, the services have been in high demand, so there was no need of organized sales. Customers proactively demanded services. The companies faced with higher demand than their available capacities to deliver the services. The competition at the market hardly existed, because most often only one operator was available on a certain territory. At that point of time, sales force motivation systems did not exist (Figure 2). 


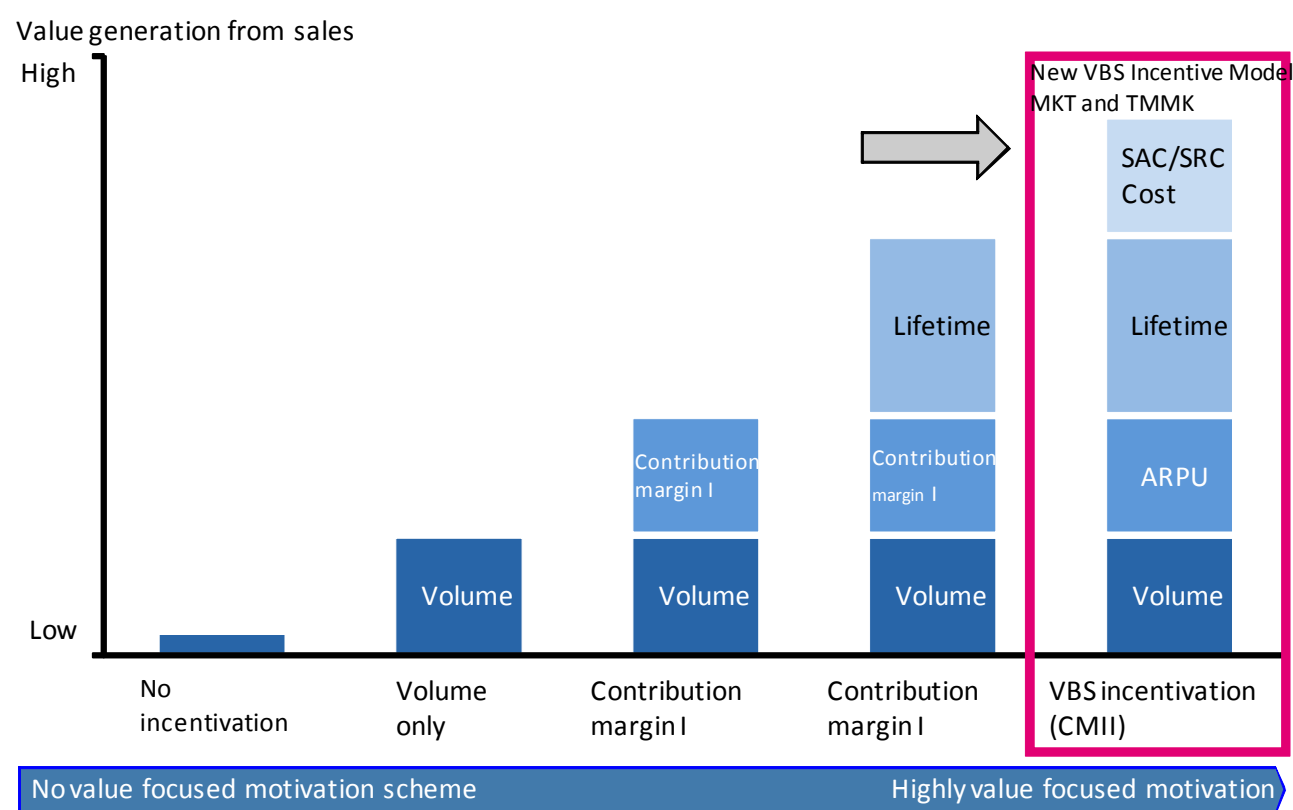

Fig. 2. Model types

The first motivational models appeared at the same time with the development of the competition. The operators put efforts to attract as many customers as possible. The motivation models were based on the number of sales transactions, based on a very simple principle: each salesperson should sell a certain number of telephone lines. If the set target is achieved, an adequate motivation follows.

Parallel to the development of the competition, along with the growth of the product portfolios with services such as internet, mobile phones, television, and others, a need arose for organization and development of sales networks that will put greater efforts to sell more than the competition. The key indicator for sales quality was the number of sold services with the level of profitability as an additional criterion. For the first time, a gradual motivation system was developed, that acknowledges the level of profitability of the transaction when the incentive is paid.

The next level of development of the sales motivation models in the telecommunications industry is a result of the stronger competition at the market. With the appearance of a greater number of operators, the customers are in a favourable position and often change them, sometimes causing loss to the operator. Therefore, the companies introduce protection mechanisms that aim to increase the lifetime of their customers. Thus, this indicator was directly introduced in the motivation models.
In addition to the quality of sales, the incentive also depends on a second quality parameter, which is the lifetime of the customer; the longer the customer is committed to use the service, the higher incentive will be paid (Figure 2).

The competition at the telecommunications market in the last couple of years reaches its zenith. There is fight over each customer. Each operator returns part of the profit to the market where it is present, by supporting different types of investments, which unlike the investments in infrastructure, they reduce the profit without offering any advantage. Recently, the operators have directly invested into the process of acquisitioning customers and service provisioning. Investments in the sales force and direct marketing have been increased. This investment becomes a significant part of the cost for service provisioning. Therefore, an additional dimension has been included in the management of the sales transactions. Subscriber acquisition cost (SAC) and a subscriber retention cost (SRC) have been introduced. These are subsidies for the customer given as a discount when telephone is purchased, or a discount to the monthly subscription fee. These two parameters are the key vector of the modern sales force motivation systems.

In addition to the SAC/SRC parameters, the model for sales force motivation should incorporate the following parameters (Figure 2): 
- Number of transactions;

- Contribution margin on the level of direct cost;

- Lifetime.

This model is named value based model for sales force motivation (VBS model). This model creates balance or a link between the value of the subsidy to the customer and the total sales cost to the user. These two indicators are inverse. The higher the investment in the customer, the easier is the sales.

The aim of defining this kind of motivation system is to define proportion between the profitability of each sales transaction in the lifetime of the customer, and the payment of the incentive directly lineked to the value add $(V A)$ generated by the transaction.

$$
\text { pay. }[\text { money }]=\sum_{i=1}^{n} y\left(a_{i} \ldots a_{p}\right) \cdot V A_{i}
$$

In which $y\left(a_{1} . . a_{p}\right)$ is a function that defines the percentage of the value added $V A_{i}$ that the telecom operator pays as an incentive for the acquired customer. This function is dependent on different factors al..ap, such as: level of accomplishment of the sales target and proportion related to it, available budget for incentives, product category, positioning of the product at the telecommunications market, the sales channel that makes the transaction, comparability among the sales channels if the sales transaction is not made through one channel only, etc.

If for $V A_{i}$ we substitute the previously defined equation

$V A(C M 2)=\sum_{i=1}^{\substack{\text { total } \\ \text { volumen }}}\left(A R P U_{i}-\right.$ DirectCost $\left._{1}\right) \cdot$ LifeTime $-M I_{i}$

and we fix exactly the $i$ - transaction, we will come to the general function of the VBS-based motivation system:

$$
\begin{array}{r}
\text { pay. }[\text { money }]=\sum_{i=1}^{n} y\left(a_{i} \ldots a_{p}\right) \cdot\left[\left(\text { ARPU }_{i}-\text { DirectCost }_{i}\right) .\right. \\
\left.\cdot \text { LifeTime }--M I_{i}\right]
\end{array}
$$

This equation calculates the value of the incentive from sales transactions only - hard payment. Usually, the sales force motivation models include quantificator that evaluates customers' satisfaction, i.e. whether the customer is satisfied with the service provided by the salesperson, whether the service was well explained, whether he received support for setting the device, was the salesperson kind, etc. This part is called soft evaluation. It is conducted on the basis of customers' surveys, interviews, etc. Other KPIs that are clearly defined and measurable were well defined.

The value of this soft payment can be fully independent from the payment received by the hard payment, or it can be proportional to it. The most frequently used model is the one in which the final payment directly correlates to the sales incentive payment, corrected as per the quality of the evaluation in the soft part:

$$
\text { pay.total }[\text { money }]=\operatorname{Soft}\left(k_{1} \ldots k_{i}\right) \cdot \text { pat. }[\text { money }],
$$

in which $S o f t()$ is a function that connects the predefined KPIs that reflect customers' satisfaction.

There are other relations between the soft and the hard parts, i.e. they can be mutually independent, double dependence on the hard part, etc.

$$
\begin{gathered}
\text { pay.total }[\text { money }]=\operatorname{Soft}\left(k_{1} \ldots k_{i}\right)+\text { pat. }[\text { money }], \\
\text { pay.total }[\text { money }]=\operatorname{Soft}\left(l_{1} \ldots l_{i}\right)[\text { money }]+ \\
+\operatorname{Soft}\left(k_{1} \ldots k_{i}\right)[\text { money }] \cdot \text { pay. }[\text { money }],
\end{gathered}
$$

The final link is a management decision that depends on the market conditions and the positioning of the telecommunications company.

In order to have a complete model, well accepted by the employees as an incentive model, in addition to the exactness of the calculations, it should also have the following characteristics:

- Minimal guarantied salary that the employee receives to cover their basic costs. The incentive is paid on top of the salary.

- A minimum threshold below which incentive is not paid

- Simplicity - each transaction has to have a clearly defined value.

- Transparency-each of the employees has to have real time information about the work he accomplished and the incentive for it.

- Sustainable design, with a modular approach adjusted towards the quick changes of the product portfolio and market conditions.

- Flexibility to market conditions changes, the fast technology development, and the product development. 
Then the sales force motivation models are created, in addition to the calculation model as a basis for exactness and transparency, in the transaction value procedure, processes for setting targets, evaluation period, and an IT infrastructure for monitoring of the results in real time.

\section{IT AND NT IMPLEMENTATION}

One of the basic components of the sales force motivation system is the IT tool. It enables the key characteristics of the system, such as:

- Transparency,

- Simplicity,

- Flexibility,

- real time information.

Without an IT system, sales force management would be almost impossible. All the previously defined critical characteristics would lose their sense without an IT system. The timely monitoring of results, the real time management, and the coverage of the sub process of setting targets and evaluation with an automated system are its key advantages. All these functionalities gain higher importance, and it can be concluded that it is impossible to implement this type of system without IT support, by telecom operators which by their size belong to the pan-continental operators, with several thousands of employees, organized by different regions dispersed in different places and managed in different types of sales channels with their own specificities.

For the implementation of the tool that will support the value based sales force motivation system, several adjustments of the existing IT systems implemented in the telecom operator are needed. To create a product catalogue for the motivation model, a direct intervention in the Customer Relation Management (CRM) system is needed, in two main modules. Initially, information about the incentive paid to employee in case of sales of a certain service line should be added to the CRM product catalogue. To ensure that this information is available, an analysis should be conducted in the frame of the data ware house (DWH), in which the historic data on the lifetime of the product are kept. Based on the DWH data and the calculative model, additional attribute in the model is given, which provides information about the payment amount.

The second upgraded module is the one on proactive sales and preparation of a dedicated of- fer. This module should create offers for the end user, based on the DHW historic data on the customers' habits and needs. This information is accessible to the employee in direct contact with the customer, aiming to have value-add steered sales. During the sales, the employee optimizes the customers' needs and the maximized personal income, based on the several pre-defined offers received by the DWH module.

With these adjustments, further implementation of the IT tool for sales force motivation is enabled.

The sales force motivation system is an information system which includes aggregated information from different disciplines: product structure, customers' habits and segmentation, volume sales, and type of sales.

For this reason, the system has direct links to almost all basic IT systems within a telecom operator (Figure 3). The application is composed of several modules, as follows:

- Product catalogue.

- Module for setting sales target - soft and hard indicators.

- Module for operational organization of the sales force $=$ organization of channels, hierarchical organization, and hierarchy of application users.

- Reporting and analysis module.

- Interface for sales force monitoring and management - cockpit.

- Incentive payment module.

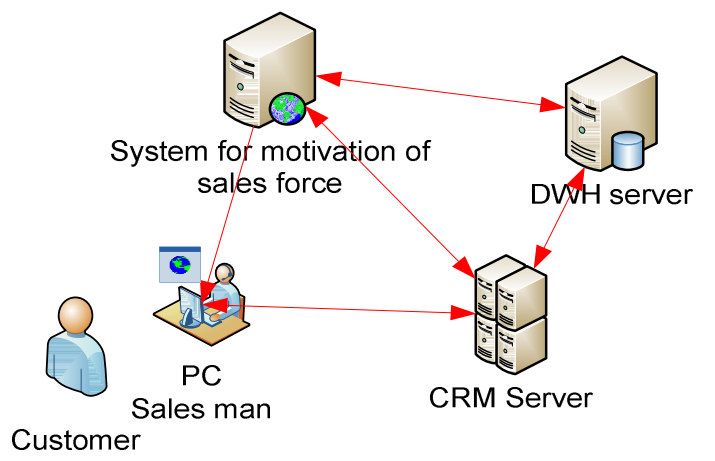

Fig. 3. IT infrastructure

The product catalogue is a module that aims to set the value based evaluation of the sales transactions (Table 1). It is directly linked to the CRM and DWH systems. Its second function is to enable transparent overview of the values: 
Table 1

Product catalogue

\begin{tabular}{llccc}
\hline Product & $\begin{array}{c}\text { Product } \\
\text { group }\end{array}$ & $\begin{array}{c}\text { Focus } \\
\text { product }\end{array}$ & $\begin{array}{c}\text { Payment } \\
\text { amount }(€)\end{array}$ \\
\hline 1 & Product 1 & Convergent & 1,3 & 1.5 \\
2 & Product 2 & Convergent & 1,2 & 1.75 \\
3 & Product 3 & Voice & 1 & 0.75 \\
4 & Product 4 & Voice & 1 & 0.5 \\
5 & Product 5 & Data & 1 & 0.68 \\
6 & Product 6 & Data & 1 & 0.99 \\
\hline \hline
\end{tabular}

The sales target setting module is composed of the following functional units: sales target distribution per sales channel, sales target distribution per region, sales target distribution per employee, defining soft target criteria, and soft target setting. The aim of this module is distribution of the company goals to each involved stakeholder, as well as setting sales target per employee.

The operational organization module defines the roles and the structure of the system users from an IT perspective, e.g. administrators, business side, system administrators, end users, as well as their hierarchy in the context of regional structure and organizational positioning.

The reporting and analysis module contains reports used for monitoring of the sales performance and contains information needed for sales channel management.

The interface seed by the employees who follow the basic sales performance indicators is presented in Figure 4.

This interface enables that the employees have real time monitoring of their personal results.

The last module is the one on incentive calculation.

The sales force motivation system should be available at real time to every sales location and ever sales representative, in order to have fully achieved functionality, but also the sense of its existence. Parts of the employees are located in the premises of the telecom operator, but it should be ensured that those who are out of the premises should have access to the motivation system.

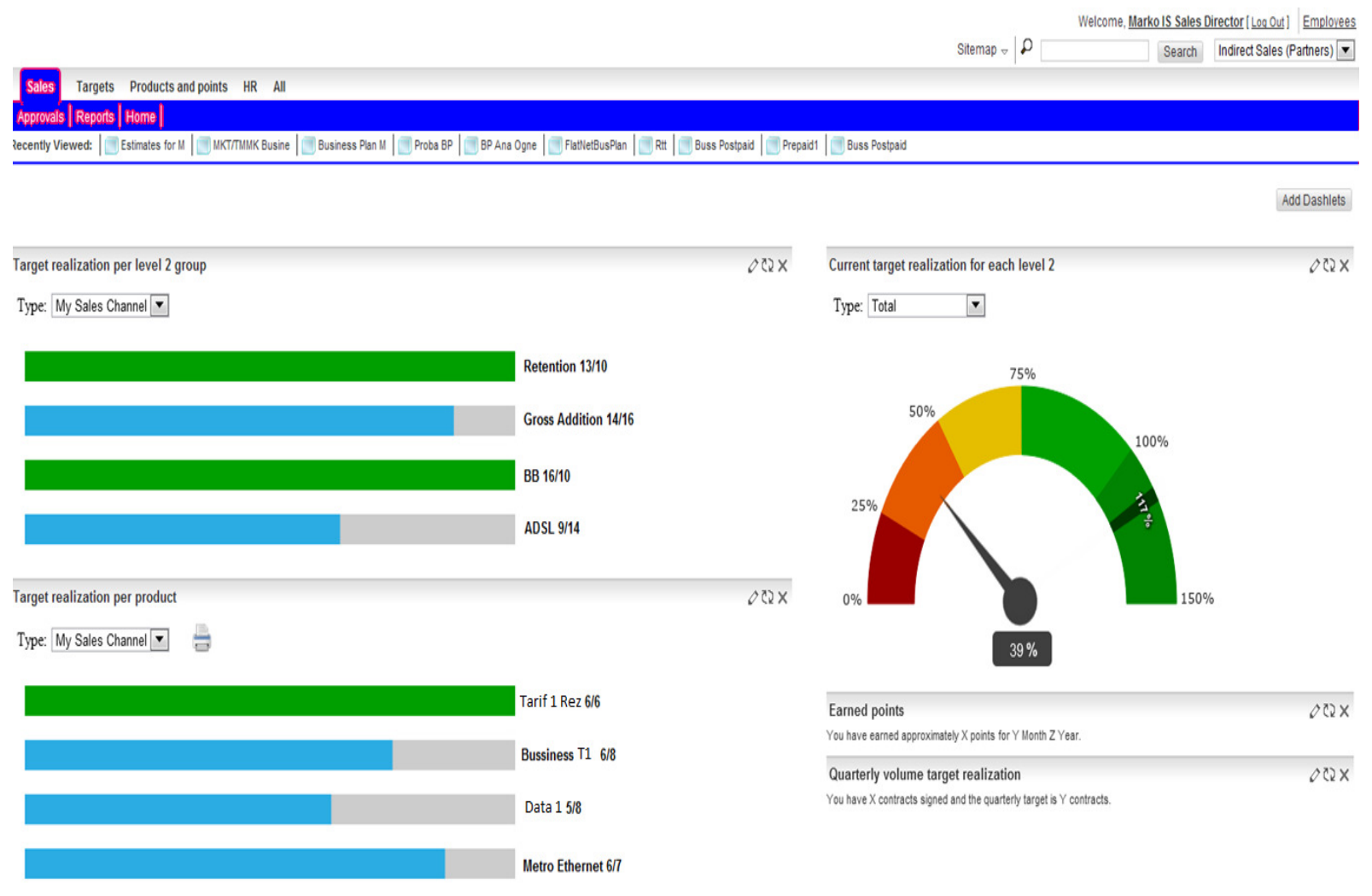

Fig. 4. Sales Performance Cockpit 
The network infrastructure should be divided into three separate logic zones (Figure 5). A server farm composed of two categories of systems: applicative and DWH systems, which represent the inner side of the system. They are organized in a cluster due to the need of redundancy. The application servers are placed in a separate demilita- rized zone (DMZ). The application is hosted on a web server, to ensure easier access through HTTP or HTTPS protocol in dispersed locations due to the topology of the sales persons in different sales channels. The access to internet should be protected by a firewall system.

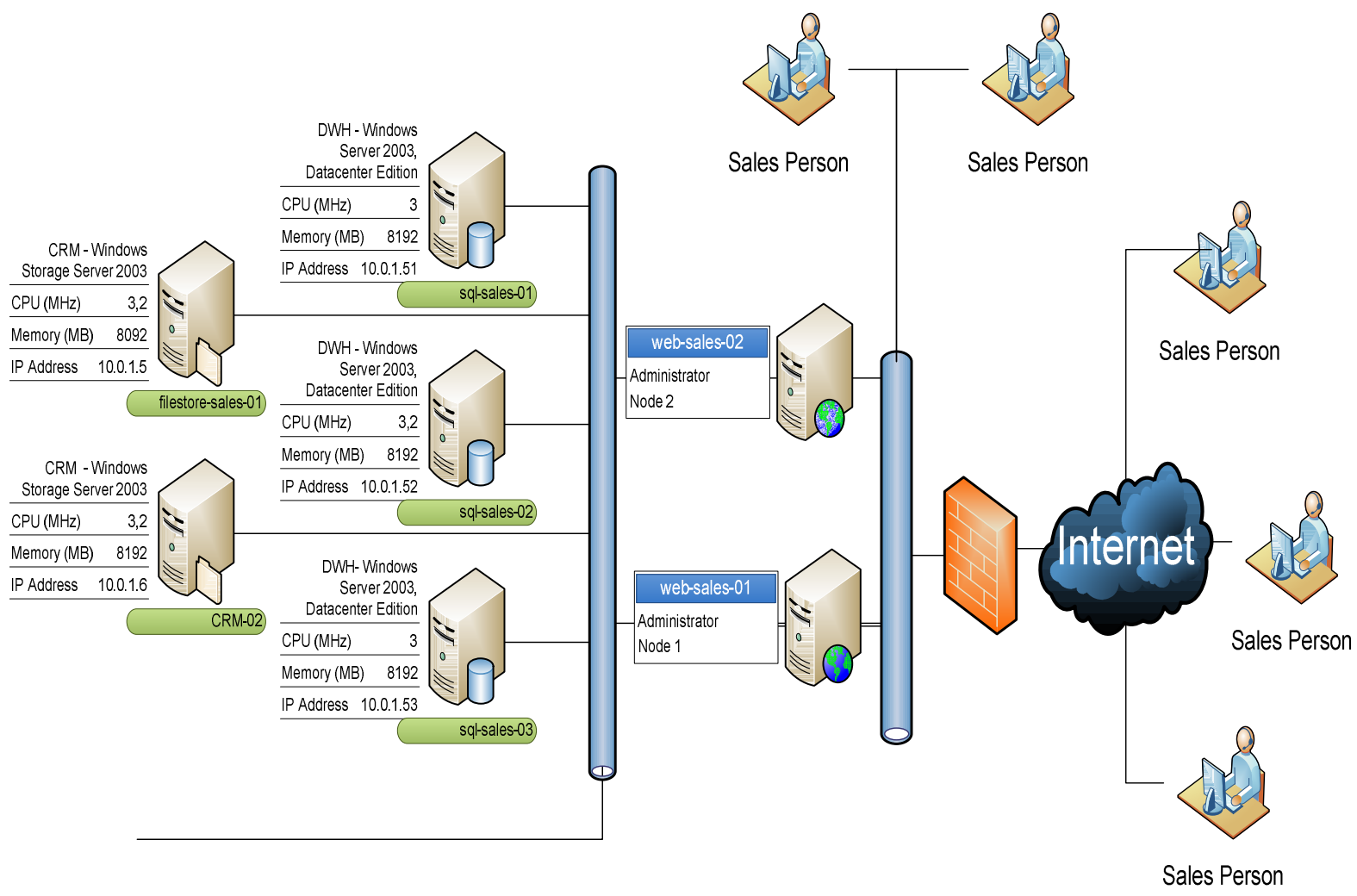

Fig. 5. Network Infrastructure

\section{CONCLUSION}

This paper presents the latest trends in the business management development in the field of telecommunications. Its main focus is the sales force motivation systems with specific implementation. There is only one method for surviving on the market of telecommunication; to find qualified difference and to optimize the work.

The bases for the operations of the telecom operators, aiming to create qualitative difference, are those aspects that are presented in this paper: optimal management models with maximizing value add and cost reduction.

The presented business models are in line with the time in which the telecommunications op- erators function, the market conditions, and the customers' demands. They support the technology development and enable different mechanisms in the segment of marketing communications and sales force organization. A direct link is made between the sales and the expectations by the management. It can be concluded that for a telecommunications operator to survive in this chaotic market, the following aspects in its work should be introduced and maintained: advanced value based business models and a motivated sales force with a value add incentive system. The companies set on solid foundations, will keep the pace with the time and successfully deal with the global and local challenges. 


\section{REFERENCES}

[1] Schoening, H. M.: Business Management of Telecommunications, Prentice Hall, 2004.

[2] Majumdar, S., Vogelsang, I., Cave, M.: I Handbook of Telecommunications Economics, Vol. 1 and 2, North Holland, 2006.

[3] Kotler, Philip, Keller, Lane: Marketing Management, Prentice Hall, 2005

[4] CISOCO - Fixed Mobile Convergence for the Enterprise, http://www.cisco.com/c/en/us/solutions/collateral/enter-p rise-networks/enterprise-fixed-mobile-convergence-soluti ons/net_implementation_white_paper0900aecd806ec474. pdf.
[5] Annabel Z. Dodd: The Essential Guide to Telecommunications, 5th ed. ISBN-13: 978-0-13-705891-4

[6] Koller Timothy: What is value-based management, http //www.mckinsey.com/business-functions/strategy-and-co rporate-finance/our-insights/what-is-value-based-manage ment

[7] Joisten, Daniel, Krebs, Marco, Biermann, Holger: Sales Performance Management, https://www.detecon.com/en/ Publications/sales-performance-management-2011.pdf, 2011

[8] Value Based Management, http://www.valuebasedmana geme nt.net [2017]

[9] Magyar Telekom PLC. http://www.otcmarkets.com/edga r/GetFilingPdf?FilingID=7815964 [2011] 
